\title{
OBSERVATION OF SIMULATED ACID RAIN IMPACT ON CHICKPEA PLANT
}

\author{
Abrar Ahmad Khan and Mustabeen \\ Department of Botany, Aligarh Muslim University, Aligarh-202002, India \\ Email: abraramu@ rediffmail.com
}

\begin{abstract}
The effect of simulated acid rain (SAR) on plant growth, yield and photosynthetic pigments of chickpea (Cicer areitinum L.) var.T-3 was studied in glass house condition. Three acidity levels, $\mathrm{pH}$ 5.0, 4.0 and 3.0 ( $\mathrm{IN} \mathrm{H}_{2} \mathrm{SO}_{4}$ and $\mathrm{IN} \mathrm{HNO}_{3}$ ) were applied twice in a week on chickpea plants. Symptoms like yellowing, lesions on lamina and marginal necrosis were observed with variations in all treatments. Plant growth, yield and photosynthetic pigments were reduced in all the treatments being highest at $\mathrm{pH}$ 3.0. Thus acid rain was found harmful to chickpea crop.
\end{abstract}

Key words: Acid rain, chickpea, growth, symptoms, yield.

\section{INTRODUCTION}

Acid precipitation due to reaction of primary gaseous pollutants SOx and NOx in the atmosphere causes stress in agricultural crops (Kausar et al. 2005). Herbaceous plants are more susceptible than woody plants to direct injury (Heck et al. 1986). Several reports show that simulated acid rain has caused reduction in growth, yield and morphological and biochemical changes of corn, green pepper, tomato, potato and wheat (Shripal et al. 2000, Dursun et al. 2002, Kausar et al. 2005, 2010). However, plant species differed in their responses. The available information is too meagre to make generalization. But studies indicate that acid rain is harmful to the plants.

Pulses the most important crops grown throughout the India, are the chief source of protein particularly to the vegetarian population of the country. Chickpea commonly known as gram is a main pulse crop. It is an herbaceous plant. Thus, it is expected that this may also suffer from acid rain. The impact of acid rain on chickpea has not been observed so far. In the present study, it was planned to evaluate the effects of acid rain on performance of chickpea.

\section{MATERIALS AND METHODS}

\section{Preparation of simulated acid rain (SAR)}

Different $\mathrm{pH}$ levels (5.0, 4.0 and 3.0) were developed by mixing of $1 \mathrm{~N}_{2} \mathrm{SO}_{4}$ and $1 \mathrm{~N} \mathrm{HNO}_{3}$ in ratio of 3:1 in distilled water. The $\mathrm{pH}$ was measured with the help of a digital $\mathrm{pH}$ meter. The different $\mathrm{pH}$ levels were prepared each time freshly just before each exposure.

\section{Plant culture and treatments}

Seeds of chickpea variety T-3 were surface sterilized (dipped in $0.01 \% \mathrm{HgCI}_{2}$ solution) for 15 minutes followed by three washings with distilled water. The clay pots were filled with soil and composed manure at the ratio of 3:1, respectively. After filling, the pots were autoclaved at $20 \mathrm{lb}$ 
pressure for 20 minutes. Three seeds were sown in each pot. After germination, thinning was done to maintain one healthy seedling per pot. Each SAR treatment was replicated five times including control.

Twenty-day old seedlings were treated with different levels of SAR having pH 5, 4.0 and 3.0, separately. Control set was showered with distilled water (DW). Each set was treated with required levels of SAR inside an exposure chamber for about $4 \mathrm{~mm}$ rain with the help of spray nozzle from the exhaust duct. Treatment was given twice in a week till 70 days. After each exposure all pots were kept on glass house bench and arranged in complete randomized block design. The temperature was maintained at $27 / 23^{\circ} \mathrm{C}$ (day/ night). The pots were irrigated on alternate days. The experiments were terminated after 70 days and plants were uprooted carefully. Roots were washed thoroughly under tap water to remove soil particles and debris. Plant growth (length, fresh and dry weights of root and shoot as well as number of nodules) and yield (number of pods, fresh and dry weights of pods, number of seeds per pod and weight of 20 seeds) parameters were taken.

After 60 days of sowing photosynthetic pigments were determined by taking $1 \mathrm{~g}$ of fresh leaves and grounded in $80 \%$ acetone with the help of mortar and pestle. The suspension was filtered through the Whatman Filter Paper No. 1 into a 100 $\mathrm{ml}$ volumetric flask and volume was maintained by adding $80 \%$ acetone. Further the method of MacLachlan and Zalik (1963) was used for the estimation of carotenoids and chlorophylls (chl a, chl $b$, and total chl $a+b)$. Data were subjected to one way ANOVA to determine the significant differences among different treatments (Dospekhov 1984). Duncan's multiple range test was employed to identify significant effects.

\section{RESULTS}

The symptoms like injuries on the apex, necrotic lesions over the surface of whole lamina were seen after $5^{\text {th }}$ spraying in $\mathrm{pH} 3.0$ treatment. All the levels of acid rain caused significant reduction in plant growth (length, fresh and dry weights of shoot and root, number of nodules) and yield (number of pods / plant, number of seeds / pod, fresh and dry weights of pods and weight of 20 seeds) as compared to control (Tables 1 and 2).

However, the reduction caused by $\mathrm{pH} 3.0$ acid rain was greater than $\mathrm{pH} 4.0$ and $\mathrm{pH} 5.0$ in plants. All levels of acid rain were found harmful to this crop.

Table 1. Effect of different levels of simulated acid rain on plant growth of Cicer areitinum var. 'T-3'.

\begin{tabular}{cccccccc}
\hline $\begin{array}{c}\text { Treatment } \\
(\mathbf{p H})\end{array}$ & \multicolumn{2}{c}{ Length $(\mathbf{c m})$} & \multicolumn{2}{c}{ Plant Growth } & \multicolumn{2}{c}{ Fresh wt. $(\mathbf{g})$} & \multicolumn{2}{c}{ Dry wt. $(\mathbf{g})$} & No of \\
& Shoot & Root & Shoot & Root & Shoot & Root & nodules \\
\hline \multirow{2}{*}{ Control } & $32.5 \pm$ & $23.8 \pm$ & $9.23 \pm$ & $2.40 \pm$ & $2.58 \pm$ & $0.75 \pm$ & $115 \pm$ \\
& $0.58 \mathrm{a}$ & $0.21 \mathrm{a}$ & $0.12 \mathrm{a}$ & $0.04 \mathrm{a}$ & $0.02 \mathrm{a}$ & $0.07 \mathrm{a}$ & $2.00 \mathrm{a}$ \\
& $27.0 \pm$ & $18.0 \pm$ & $6.52 \pm$ & $1.99 \pm$ & $1.61 \pm$ & $0.56 \pm$ & $94 \pm 1.48 \mathrm{~b}$ \\
& $0.55 \mathrm{~b}$ & $0.17 \mathrm{~b}$ & $0.04 \mathrm{~b}$ & $0.02 \mathrm{~b}$ & $0.01 \mathrm{~b}$ & $0.04 \mathrm{~b}$ & \\
& $23.1 \pm$ & $15.7 \pm$ & $4.58 \pm$ & $1.47 \pm$ & $1.56 \pm$ & $0.33 \pm$ & $78 \pm 1.35 \mathrm{c}$ \\
& $0.53 \mathrm{c}$ & $0.14 \mathrm{c}$ & $0.03 \mathrm{c}$ & $0.03 \mathrm{c}$ & $0.02 \mathrm{c}$ & $0.02 \mathrm{c}$ & \\
& $19.2 \pm$ & $14.2 \pm$ & $3.94 \pm$ & $0.98 \pm$ & $0.93 \pm$ & $0.25 \pm$ & $62 \pm 1.00 \mathrm{~d}$ \\
& $0.53 \mathrm{~d}$ & $0.12 \mathrm{~d}$ & $0.02 \mathrm{~d}$ & $0.01 \mathrm{~d}$ & $0.01 \mathrm{~d}$ & $0.01 \mathrm{~d}$ & \\
\hline
\end{tabular}

Each value is a mean of five replicates; \pm Standard deviation.

Different letters within vertical column indicates statistically difference in means at the 0.05 level. 
Table 2. Effect of different levels of simulated acid rain on yield of Cicer areitinum var. 'T-3'.

\begin{tabular}{llcccc}
\hline Treatment $(\mathbf{p H})$ & $\begin{array}{l}\text { No. } \\
\text { pods }\end{array}$ & Fresh wt. of pods $(\mathbf{g})$ & $\begin{array}{c}\text { Yield } \\
\text { Dry wt. of pods } \\
(\mathbf{g})\end{array}$ & $\begin{array}{c}\text { No. of seeds/pod } \\
\text { Wt. of 20 seeds } \\
(\mathbf{g})\end{array}$ \\
\hline Control & $16 \pm 0.16 \mathrm{a}$ & $4.09 \pm 0.04 \mathrm{a}$ & $1.27 \pm 0.08 \mathrm{a}$ & $2 \pm 0.03 \mathrm{a}$ & $3.37 \pm 0.04 \mathrm{a}$ \\
5.0 & $11 \pm 0.10 \mathrm{~b}$ & $2.88 \pm 0.03 \mathrm{~b}$ & $1.00 \pm 0.02 \mathrm{~b}$ & $2 \pm 0.03 \mathrm{~b}$ & $2.93 \pm 0.02 \mathrm{~b}$ \\
4.0 & $8 \pm 0.04 \mathrm{c}$ & $1.79 \pm 0.02 \mathrm{c}$ & $0.49 \pm 0.02 \mathrm{c}$ & $2 \pm 0.02 \mathrm{c}$ & $2.05 \pm 0.02 \mathrm{c}$ \\
3.0 & $6 \pm 0.03 \mathrm{~d}$ & $1.38 \pm 0.02 \mathrm{~d}$ & $0.35 \pm 0.01 \mathrm{~d}$ & $1 \pm 0.01 \mathrm{~d}$ & $1.19 \pm 0.01 \mathrm{~d}$ \\
\hline
\end{tabular}

Each value is a mean of five replicates; \pm Standard deviation.

Different letters within vertical column indicates statistically difference in means at the 0.05 level.

Table 3. Effect of different levels of simulated acid rain on photosynthetic pigments of Cicer areitinum var. 'T-3'.

\begin{tabular}{lccccc}
\hline Treatment $(\mathbf{p H})$ & No. of leaves & \multicolumn{4}{c}{ Photosynthetic Pigment (mg / g Fresh wt) } \\
& & Chl a & Chl b & Total chl (a + b) & Carotenoids \\
\hline Control & $109 \pm 1.50 \mathrm{a}$ & $1.812 \pm 0.057 \mathrm{a}$ & $1.347 \pm 0.072 \mathrm{a}$ & $3.159 \pm 0.121 \mathrm{a}$ & $0.0821 \pm 0.033 \mathrm{a}$ \\
5.0 & $93 \pm 1.16 \mathrm{~b}$ & $1.781 \pm 0.082 \mathrm{~b}$ & $1.094 \pm 0.063 \mathrm{~b}$ & $2.874 \pm 0.091 \mathrm{~b}$ & $0.0787 \pm 0.027 \mathrm{~b}$ \\
4.0 & $74 \pm 1.14 \mathrm{c}$ & $0.823 \pm 0.053 \mathrm{c}$ & $0.278 \pm 0.068 \mathrm{c}$ & $1.101 \pm 0.073 \mathrm{c}$ & $0.0370 \pm 0.022 \mathrm{c}$ \\
3.0 & $50 \pm 0.93 \mathrm{~d}$ & $0.628 \pm 0.036 \mathrm{~d}$ & $0.175 \pm 0.045 \mathrm{~d}$ & $0.804 \pm 0.056 \mathrm{~d}$ & $0.0335 \pm 0.016 \mathrm{~d}$ \\
\hline
\end{tabular}

Each value is a mean of five replicates; \pm Standard deviation.

Different letters within vertical column indicates statistically difference in means at the 0.05 level.

Number of leaves and photosynthetic pigments (chl a, chl b, total chl a+b) and carotenoids of chickpea were also reduced significantly by all the levels of acid rain (Table 3). As level of $\mathrm{pH}$ was increased, there was corresponding decrease in pigments concentration. All the above parameters were thus adversely affected with respect to acid rain levels ( $\mathrm{pH}$ 5.0, 4.0 and 3.0).

\section{DISCUSSION}

Acid rain directly causes stress to plants (Heck et al. 1986). In the present study, simulated acid rain caused yellowing, lesions and marginal necrosis on the leaves at different $\mathrm{pH}$ levels. Similar results were also observed on leguminous plants by Shriner and Johnston (1981). The plant growth and yield parameters were decreased as the level of $\mathrm{pH}$ concentration increased. The harmful effects of SAR on plant growth and yield parameters on several crops have also been reported by Evans et al. (1997), Kausar et al.
(2005, 2010), Varshney et al. (2005) and Agrawal et al. (2005).

All photosynthetic pigments were inhibited significantly at all the levels of SAR in the present study. Reduction might be due to removal of $\mathrm{Mg}^{+}$ from tetrapyrol ring of the chlorophyll molecules by $\mathrm{H}^{+}$(Foster 1990) or due to increase of transpiration by acid rain (Evans et al. 1997). Similar results were also observed on many crops like mustard, radish, potato, wheat (Agrawal et al. 2005, Varshney et al. 2005, Kausar et al. 2005, 2010).

\section{REFERENCES}

Agrawal, S., D. Raghav and A.A. Khan. 2005. An evaluation of the impact of simulated acid rain on the growth of mustard in pots. TAC Ann. Appl. Biol. (Suppl). 37:25-26.

Dospekhov, B.A. 1984. Field Experimentation. Mir Publishers, Moscow, Russia. 352 pp. 
Dursun, A., A.M. Kumlay, E. Yeilderin and I. Guvene. 2002. Effects of simulated acid rain on plant growth and yield of tomato. ActaHorticult. 579:245-248.

Evans, L.S., N.F. Gmor and F. Dacosta. 1997. Leaf surface and histological perturbations of leaves of Phaseolus vulgaris and Helianthus annuus after exposure to simulated acid rain. American Journal of Botany 4:304-313.

Foster, J.R. 1990. Influence of $\mathrm{pH}$ and plant nutrients status onion fluxes between tomato plants and simulated acid mists. New Phytology 116:475-485.

Heck, W.W., A.S. Heagle and D.S. Shriner. 1986. Effect on Vegetation in Native Crops and Forestry. Air Pollution. (ed.) Stern, A.S. New York Academic Press. 6:247-350.

Kausar, S., A.A. Khan and F. Rahman. 2005. Impact of simulated acid rain on potato. Sattelite Session, III International Conference on Plants and Environmental Pollution; December 4, Jamia Hamdard, New Delhi, pp. 78-80.
Kausar, S., M.A. Hussain and A.A. Khan. 2010. Response of simulated acid rain on morphological, biochemical and leaf epidermal characters of wheat. Trends in Biosciences 3(1):34-36.

MacLachlan, S. and S. Zalik. 1963. Plastid structure, chlorophyll concentration and free amino acid composition of chlorophyll mutant of barley. Canadian Journal of Botany 41:1053-1062.

Shriner, D.S. and J.W. Johnston. 1981. Effects of simulated acidified rain on nodulation of leguminous plants by Rhizobium sp. Environ, Exp. Bot. 21:199-209.

Shripal, K.N., S. Pal and N. Kumar. 2000. Effects of simulated acid rain on yield and carbohydrate contents of green pepper. $A d v$. Plant Sci. 13(1):85-88.

Varshney, P., S. Kausar and A.A. Khan. 2005. An evaluation of the susceptibility of radish in pots to simulated acid rain. TAC, Ann. App. Biol (suppl). 27:29-30. 